\title{
The Perspectives Of The Establishment Of International Financial Centers In Uzbekistan And The Implementation Of English Law
}

\author{
${ }^{1}$ Otabek Narziev, ${ }^{2}$ Mukhammad Ali Turdialiev, ${ }^{3}$ Sherzod Khodjimurotov, ${ }^{4}$ Sardor \\ Mamanazarov
}

${ }^{1} \mathrm{PhD}$ in Law, Department of International private law, Tashkent state university of Law, Tashkent, Uzbekistan. ${ }^{2}$ Lecturer, Department of International private law, Tashkent state university of Law, Tashkent, Uzbekistan.

${ }^{3}$ Lecturer, Department of International private law, Tashkent state university of Law, Tashkent, Uzbekistan.

${ }^{4}$ Lecturer, Department of International private law, Tashkent state university of Law, Tashkent, Uzbekistan.

E-mail: otabeknarziev@tsul.uz

Article History:Received:11 January 2021; Accepted: 27 February 2021; Published online: 5 April 2021

\begin{abstract}
In this article analyzed main notions of international financial center and its brief history, and the views of several scientists from different countries about international financial centers and its types. Moreover, it is also researched the perspectives of the establishment of international financial centers as one type of free economic zones in Uzbekistan. In addition, in this article researched the main features of common law, its implementation as a special legal regime on regulating international financial centers in Uzbekistan. As result of analyzes, it is illustrates legal, financial and other potential of establishment common law based international financial center as a type of free economic zone in Uzbekistan.
\end{abstract}

Keywords: Financial centers, International financial centers, free economic zones, security market, special legal regime, investment, economic potential.

\section{INTRODUCTION}

Today, Uzbekistan is one of the most developing countries in Central Asia. Because Uzbekistan had already chosen its development strategy in the initial years of independence, these strategies have been showing their expected consequences. The high economic growth of Uzbekistan can support this idea.

In recent years, there has been a tendency for the growth of free economic zones in the world, the further development of foreign trade and investment relations, the increasing of foreign direct investment in these regions and the creation of new high-tech industries, as well as significant production of competitive and export-oriented products. The development of entrepreneurial activity in these structures shows the necessity for its legal regulation. Currently, there are more than 4300 types of free economic zones in the world. International financial centers are a new form of free economic zones.

\section{Materials and Methods}

This research has been conducted using literature review and publication research, comparative analysis and empirical study, and other techniques, including historical, qualitative, and quantitative research. The consequent thesis relies on data from the reports and reviews of IOSCO, the World Bank, the OECD, the EBRD, the IMF, the ADB, and other international organizations and other specific research.

\section{Results}

The researches ultimate goal is to developing mechanism of establishment international financial centers as s type of free economic zones and implementation of common law into financial center. Moreover, different aspects of applying common law into free economic zones, especially, Navoi free economic zone. The analysis assumes that complex legal and institutional reforms will serve the development of free economic zones and its effects on inclusive economic growth in the region.

The achieved results would be use as teaching materials for master and bachelor degree students. The procedure of creating international financial centers, which achieved results from research can be use main conception of implementing common law into special economic zones and establishment of international financial center in Uzbekistan.

\section{Discussion}

International financial centers - is a new generation of free economic zones. They include banks and specialized financial institutions involved in international financial transactions, lending and finance, securities, and gold transactions. Major global financial centers worldwide are located in London, New York, Zurich, Frankfurt, Luxembourg, Singapore, and other countries. In particular, in 2018, the Astana International Financial Center was established in the neighboring Republic of Kazakhstan. This, in turn, testifies to the vital role of international financial centers in the country's economy.

We believe that Uzbekistan should also apply British law in the activities of free economic chambers. Before studying Kazakhstan's experience in establishing the International Financial Center, using English law, and establishing international arbitration centers, we examined Qatar's expertise and English law application in them. Based on the study results, we can say that this system is useful in Uzbekistan as well. In particular, 
Kazakhstan and Uzbekistan have common goals: to attract investors, to develop business internationally. Therefore, Uzbekistan will also benefit from choosing this path.

Among the financial instruments, mechanisms, and institutions, the economic infrastructure's main features, the complex that combines its nature, are the international financial centers.

The concept of an international financial center was first known as a "global city." The term was used in 1918 by O. Shpenlerov [2] to mean "Global city - a place where a combination of small types of monetary transactions." Because of development, the term "global city" was used instead of the word "World city".

In 1927, R. Mackenzie noted that the "World City" had developed dynamically and, as a result, had become a system of large cities that attracted entrepreneurs and the rich. [3]

According to P. Hall, the world's cities such as London, Paris, New York, Tokyo, Moscow are among the world's most developed cities. The main reason for this is that these cities have well-developed systems such as trade, finance, education, culture, and technology. [4]

Continuing his research with analyst J. Friedman, P. Hall analyzed the development history of several major cities and concluded that by 1986, these financial cities had begun to act as intermediaries to bring the national economy and credit system into the international financial market. [5]

After some time, scientists who conducted scientific research within the financial centers, according to Dj. Bivershtok, P. Taylor [6] and others, "world cities" began to be seen as cities that not only provided access to world markets but also improved the quality of life and labor of the citizens living there.

Only in 1991, scientist S. Sassen gave a precise definition of international financial centers, which is now accepted. According to him, global financial centers are highly industrialized, integrated into the world economy, and cross other large cities [7]. These financial centers host global capital that circulates and generates income around the world.

The concept of international financial centers as a global hub is characterized by convenience in urban, social, and geographic areas. It is also characterized by a high international financial capital and business environment in international financial centers. Global financial centers are viewed as a locomotive of economic development of the national and international economy by attracting financial capital from around the world. Because of their administrative and intellectual activities, global financial centers have also become centers of education, innovation, and technology development.

A financial center system allows the owner of funds to freely transfer their funds to another person on the international financial market to implement their activities fully. We can say that global financial centers may also have additional capabilities, such as a financial intermediation platform.

Based on the activities of international financial centers, we can take a twofold approach. First, international financial centers are part of the global financial market due to their economic activities. On the other hand, we can view the national economy as a macroeconomic factor that significantly affects growth.

In this context, the research researcher Ch. Kindleberger's opinion we would like to highlight. According to him, international financial centers should be located in the center of the city and its organization, taking into account its financial sector. [8]

The basis of international financial centers should be an interbank center and financial and credit institutions, including all types of banking activities. Representative offices of international banks, stock exchanges, audit, consulting companies, and government control departments play an essential role in global financial centers' activities. International financial centers are also characterized by the fact that the actions of IFC participants are closely interrelated.

To clarify the concept of international banks, international banks are a group of financial banks that carry out a wide range of international or domestic transactions.

Economist-historian Y. Cassis, according to, international financial centers should be a global financial architecture that includes essential elements of financial institutions, financial markets, and organizations, professional societies [9]. Financial centers should be a place for simultaneous money transfers, payments, and exchange transactions in economic relations.

Current views on international financial centers focus mainly on their financial intermediation activities. According to economist X. Rid, the emergence of financial centers is associated with transforming financial investments into investments [10]. Financial centers also enter economic relations as an intermediary between investors and borrowers, maintaining a balance between savings and investments.

In other words, the international financial center is:

- The global market is a mechanism that serves as an intermediary in world economic circulation;

- Center for gold, securities, currency exchange, credit and financial transactions between the Bank and specialized financial institutions;

- Center for International Asset Transactions in the city center as a significant player in the international financial markets;

- International financial intermediation for financial institutions in different jurisdictions; 
- A single-center of economic systems located in other regions based on an agreement. For example, the Swiss Financial Center. This financial center brings together the economic systems of cities such as Geneva, Lugano, and Zurich.

- a synonym for the concept of "offshore financial center", in other words, minimal or complete government intervention in the legal and financial activities of a business.

The simple concept of "financial center" can reveal the true meaning and essence of the "international financial center" idea. For example, a financial center is a city that brings together all financial institutions, works to improve economic relations and the business environment, and conducts domestic and international credit and financial transactions [11]. Using global financial centers about financial centers creates opportunities for various international financial institutions and their commercial operations in the same region. However, not all cities with the status of global financial centers have such options. For example, Hamilton International financial centers or Sydney International financial centers in Bermuda Island are also cities that have received international financial center status but cannot participate in international financial transactions. From this point of view, New York and London's financial centers are entirely global financial centers.

Z / Yen Group Limited, a British financial company, was the first to resolve this discrepancy between financial centers and international financial centers.

$\mathrm{Z} /$ Yen Group Limited lists the following activities of international financial centers.

- The Global Financial Center is a hub that reflects the world's financial institutions, connecting national, regional, and global financial institutions.

- Financial centers at the international level - are centers that act as focal points in implementing international agreements and other transactions between financial sectors located in different parts of the world.

- Specialized financial centers are among the most common types of financial centers, which are centers that coordinate the world's leading banking, insurance, and financial institutions in a specific area of the financial market. These types of financial centers will specialize in only one type of financial need.

- Financial centers at the national level - the center of trade, finance, and banking operations of the country in which the financial center is located. These financial centers are also characterized by the host country's ability to conduct international financial transactions.

- Local financial centers are smaller than other financial centers in terms of operations and financial transactions. This type of financial center is radically different from other centers in that it conducts financial transactions locally within the same country.

One financial center of the same category may also act as other economic centers. Examples include the financial centers of London and New York.

21th Clause of the Decree of the President of the Republic of Uzbekistan dated on May 15, 2019, PF-5719 "On measures to create the Navoi region as a free economic zone for innovative, high-tech, export-oriented and import-substituting industries" of the Ministry of Justice, Investments and the Ministry of Foreign Trade together with JSC "Directorate of SEZ "Navoi" and other interested ministries and departments within two months with the involvement of foreign specialists for doing business on the territory of SEZ "Navoi" "English" based on English standards, principles, and norms "to make proposals on the establishment of a separate legal regime, which provides for the regulation of relations between participants.

At present, the tendency of many countries to regulate investment relations, foreign investment in foreign economic relations, contractual relations between entrepreneurs, legal entities, various companies, and corporations by the norms of English law is growing daily. In the current integration process, English law is a norm of law that is flexible to the requirements of rapidly changing market conditions, in which there is a lack of standards, regulated only under the terms specified in the contract. Also, this trend is attracting large amounts of foreign investment in the free economic zones, companies, corporations, firms, and organizations with high potential for the introduction of modern technologies in these areas are operating under English law. The volume of trade and investment relations between these organizations and their partners based on agreements regulated by Common law rules is growing day by day.

This situation shows that the main factor in attracting investment in these free economic zones is that in the country's free economic zones, along with our national legislation, investors have the opportunity to enter into contractual relations based on English law.

The current legal regime in the FEZ of the Republic of Uzbekistan does not fully meet foreign investors' interests. This legal regime was limited to providing tax and customs benefits.

In this regard, the introduction of a new legal regime based on English law in the free economic zones of Uzbekistan: will create a favorable investment climate; simplify the system of registration of investment projects in FEZ; ensure political and economic stability in FEZ; and guarantee large investments and free trade agreements. This gives foreign investors' confidence in investing heavily in the free economic zones of the Republic of Uzbekistan. 


\section{Conclusion}

Based on the above, we would like to suggest that it is necessary to establish the International Financial Center and launch a separate legal regime in the Tashkent city international business center with all the essential facilities and infrastructure for global financial centers.

First, it is necessary to develop the legal framework and corporate governance system of the Tashkent International Financial Center. The transformation of the Tashkent city international business center into a global financial center will require about \$ 60-70 million. This amount is calculated based on international experience.

There are several strategic goals for the creation of the Tashkent International Financial Center, which should be designated as the strategic directions of the Tashkent International Financial Center:

Development of the capital market;

Development of asset management;

The attraction of Islamic finance;

Improving the quality of property management;

Development of financial technologies;

Based on the experience of the international financial centers of Astana and Dubai, the gradual creation of the Tashkent International Financial Center in the Tashkent International Business Center and the introduction of English law in it will take about five years. It will take about ten years for this international financial center to become financially independent.

Based on the international experience of creating those mentioned above global financial centers, we can say that Uzbekistan's current economic potential is sufficient to meet these requirements. In conclusion, we can positively assess the current prospects for creating the International Financial Center of Uzbekistan and the present British legislation.

\section{References}

1. Beaverstock J.V., Taylor P.G., Smith R.G. A Roster of World Cities // Cities. 1999. No. 16. Vol. 6. Pp. 445-458.

2. Cassis Y. Capitals of Capital: The Rise and Fall of International Financial Centres 1780-2009. Cambridge University Press, 2010. 4 p.

3. Friedman J. The World City Hypothesis // Development and Change. 1986. No. 4. Pp. 12- 50

4. Hall P. World Cities. New York: McGraw-Hill, 1966. 156 p.

5. Kindleberger Ch.P. The Formation of Financial Centers: A Study in Comparative Economic History. Princeton Studies in International Finance. No. 36. New Jersey, 1974. 85 p

6. McKenzie R. The Concept of Dominance and World-Organization // American Journal of Sociology. 1927. No. 33. Pp. 28-42.

7. Prospects for the establishment of an international financial center in the Russian Federation / Drobyshevsky S.M., Khudko E.V., Velikova E.E. - M .: Gaidar Institute, 2010 .-- 28 p.

8. Reed H.C. The Ascent of Tokyo as an International Financial Centre // Journal of International Business Studies. 1980. No. 11. Iss. 3. Pp. 19-35.

9. Sassen S. The Global City: New York, London, Tokyo. Princeton University Press, 1991. 480 p.

10. Spengler O. Decline of Europe. Essays on the morphology of world history. T. 2. World historical perspectives / per. with him. and note. I.I. Makhankov. M .: Mysl, 1998. 606 p.

11. Narziev, Otabek. "Problems and Prospects of Development Legal Bases of Stock Market Regulation in Uzbekistan"

12. Sadievich, Narziev Otabek. "Securities Market Development in CIS Countries: Legislative and Regulatory Lessons from Kazakhstan, Russia, and Uzbekistan." PhD diss., 神戸大学, 2019.

13. ГУЛЯМов С. С. ПРОБЛЕМЫ КОРПОРАТИВНОГО УПРАВЛЕНИЯ И ПЕРСПЕКТИВЫ РАЗВИТИЯ ЗАКОНОДАТЕЛЬСТВА УЗБЕКИСТАНА //Государство и право: проблемЫ и перспективы совершенствования. - 2018. - С. 96-99.

14. Rustambekov I. Opportunities for investment in free economic zones of the republic of Uzbekistan //Научные тенденции: Юриспруденция. - 2019. - С. 18-20.

15. Akramov A., Mirzaraimov B., Akhtamova Y. FOREIGN EXPERIENCE RELATED TO THE LEGISLATION AND PRACTICE OF TRUST MANAGEMENT OF PROPERTY IN BUSINESS ACTIVITIES //Збірник наукових праць $\Lambda$ ОГО. - 2020. - C. 12-14.

16. Akramov A. Prospectives Of Trust Management Of Property In Uzbekistan //The American Journal of Political Science Law and Criminology. - 2020. - T. 2. - №. 11. - C. 143-150.

17. БОЗАРОВ С. С. ПРАВОВЫЕ ОСНОВЫ ОСУЩЕСТВЛЕНИЯ ПРЕДПРИНИМАТЕЛЬСКОЙ ДЕЯТЕЛЬНОСТИ В СВОБОДНЫХ ЭКОНОМИЧЕСКИХ ЗОНАХ РЕСПУБЛИКИ УЗБЕКИСТАН //Право и жизнь. - 2016. - №. 5-6. - С. 91-103. 
18. Esanova Z. N., Bozarov S. S. LEGAL BASES OF ACTIVITY OF SPECIAL INDUSTRIAL ZONE “ANGREN" OF THE REPUBLIC OF UZBEKISTAN //Pridneprovskiy scientific bulletin. - 2016. - T. 11. - №. 475.

19. Mirzaraimov B. Effective Measures Of Preventing Due Process Paranoia In International Arbitration //The American Journal of Political Science Law and Criminology. - 2020. - T. 2. - №. 11. - C. 72-80.

20. Akhtamova Y. Protection of International Investments. Analysis of Certain Clauses in International Agreements. Uzbekistan Case Study //Analysis of Certain Clauses in International Agreements. Uzbekistan Case Study (March 25, 2016). - 2016.

21. МАМАНАЗАРОВ С.Ш. АКЦИЯДОРЛИК ЖАМИЯТИ ИЖРОИЯ ОРГАНИ: БОШҚАРУВ ВА РАХБАРЛИКНИ АМАЛГА ОШИРИШНИНГ ХУҚУҚИЙ АСОСЛАРИ // Юрист ахборотномаси - Вестник юриста - Lawyer herald. № 6 (2020), Б. 62-66.

22. Turdialiev M. A., Komilov B. The Legal Issues Of International Investment Activity In Uzbekistan: Critical Analysis And Legal Solutions //The American Journal of Political Science Law and Criminology. - 2020. - Т. 2. - №. 12. - С. 16-21.

23. ТУРДИАЛИЕВ М.П. ЭРКИН ИҚТИСОДИЙ ЗОНАЛАР ДОИРАСИДА ИНГЛИЗ ХУҚУҚИНИ ЖОРИЙ ЭТИШНИНГ ХОРИЖ ВА МИЛЛИЙ ТАЖРИБАСИ // Юрист ахборотномаси - Вестник юриста - Lawyer herald. № 6 (2020), Б. 153-158. DOI http://dx.doi.org/10.26739/2181-9416-2020-623

24. Narziev, Otabek. "Securities Market Regulation Theories and Perspectives of their Improvement." Available at SSRN 3622883 (2020).

25. НАРЗИЕВ О.С. КАПИТАЛ БОЗОРИ БИЗНЕСНИ МОЛИЯЛАШНИНГ МУКОБИЛ МАНБАСИ СИФАТИДА // Юрист ахборотномаси - Вестник юриста - Lawyer herald. № 6 (2020), Б. 37-44

26. Otabek Narziev, Towards Medium Long-Term Development Of Uzbekistan Stock Market, UJOLS, 2018, Vol.3. http://ujols.org/wp-content/uploads/2018/03/Otabek-Narziev.pdf

27. Bozarov S. S. Prospects for the innovative development of free economic zones in the Republic of Uzbekistan //Review of law sciences. - 2018. - T. 2. - №. 1. - C. 23.

28. Akhtamova, Yulduz. "EU Freedom Of Establishment And The Theories Of Incorporation In The Context Of Free Movement Of MNEs." The American Journal of Social Science and Education Innovations 2.12 (2020): 303-312. 